\title{
From Internal to International Migration in Romania - Continuity and Spatial Differentiation
}

\section{Ionel MUNTELE ${ }^{* 1}$, Raluca-Ioana HOREA-ȘERBAN*2}

\begin{abstract}
The study proposes a set of analyses on the evolution of the migration balance of Romania's population over a wide time interval, fully covering the period dominated by the communist regime (1948-1989) and the last three decades marked by the transition to a market economy. The aim is to differentiate the typology of the time and space distribution of the mentioned indicator and to test a set of explanatory factors, for each of the two distinct periods. The typological and factor analyses applied led to results that largely confirm the hypothesis of a continuity between the massive internal migration during the communist regime and the more complex migration in recent decades. At the same time, the profound changes in the incidence of certain explanatory factors certify a complete restructuring of the migration system in Romania after 1990. The massive migration from rural to urban areas, brought about by positional or socio-economic factors, was gradually replaced after the fall of the communist regime by a strong labour emigration, an effect of deindustrialization. The stimulation of the periurbanization process, by changing the way of life, introduced new variables in the functioning of the migration system, in keeping with the specific evolutions of the contemporary era.
\end{abstract}

Keywords: mobility transition, territorial disparities, mygratory sistem, changing trends, predictors, Romania.

JEL Code: O15;R23

\footnotetext{
${ }^{* 1}$ Ionel Muntele is professor at "Alexandru Ioan Cuza" University of Iași, Romania and Senior Researcher at Romanian Academy, Iaşi Section, Geography Team (imuntele@yahoo.fr; ORCID: 0000-0002-6242-850X).

${ }^{* 2}$ Raluca-Ioana Horea-Șerban is lecturer at "Alexandru Ioan Cuza" University of Iași (ralusel@yahoo.com; ORCID:0000-0001-5678-2097).
} 


\section{Introduction}

The relationship between domestic and international migration is less frequently addressed, researchers' attention being usually focused on one of them. The links between them are acknowledged especially from the perspective of their impact on urbanization or of the multiform transition of society demographic, urban, economic etc. (Skeldon, 2017). More than ever, contemporary migration processes cross, requiring a unitary approach, based on the diversity of forms generated by the increasingly complex political, social and economic context (Smith, 2011; King, 2011). The transition from a predominantly internal mobility to a predominantly international one, in the particular case of Romania, involves a good knowledge of the mechanisms that created specific mobility patterns. The population's adaptation to the new context generated by the fall of the communist regime thus gradually entailed the transformation of internal migration flows into international migration flows, going through the intermediate, conjunctural phase of returning to the localities of origin. The connection between domestic and international in terms of population migration can be seen either as a complementarity or as a process of substitution, the Romanian case rather fitting the latter (Bernard, Perales, 2021).

The present study proposes, in its first part, a descriptive analysis of the combined evolution of internal and international migration in Romania between 1948 and 2020, using as a variable the migration balance, extracted from the population balance. Making use of a series of explanatory variables, the second part proposes a factorial analysis meant to capture the existence of some correlations between the evolution of the migration balance and the specific economic, social or cultural context. The separation of two distinct periods, 1948-1992 and 1992-2020, marked by the predominance of domestic migration and emigration respectively, allows highlighting some elements of continuity between the two forms of mobility. The distinction between the two periods has been analysed in various studies (Horváth, 2016) and is closely linked to the emergence of some increasingly pronounced disparities in gross domestic product and life quality (Bunea, 2012). These analyses want to answer the question of the existence of a continuity regarding the internal and the international migration in Romania from a spatial perspective. The 
study may be relevant from the perspective of understanding the relationship between migration and development.

Starting with the year 1912, three distinct phases of unequal amplitude can be separated in the evolution of the mobility of Romania's population, following the dynamics of the migratory balance over a long period (Figure 1):

1. 1912-1960, marked by a certain equilibrium of the migration balance, close to the value of 0 , episodically interrupted by the two world conflagrations, with a disruptive effect;

2. 1960-1990, when this balance is disturbed by the incidence of ethnic migration, first of Jews (1960-1970), then of Germans and Hungarians (especially after 1980). This transition period ends with the deepening of the negative character of the migration balance, Romania thus becoming a net supplier of migrants;

3. After 1990, when the strengthening of the ethnic migration after the fall of the communist regime sustainably leads to the generalization of the external migration for work, a more and more consistent part of it turning into definitive emigration.

Figure 1. Evolution of migration balance in Romania (1912-2019)

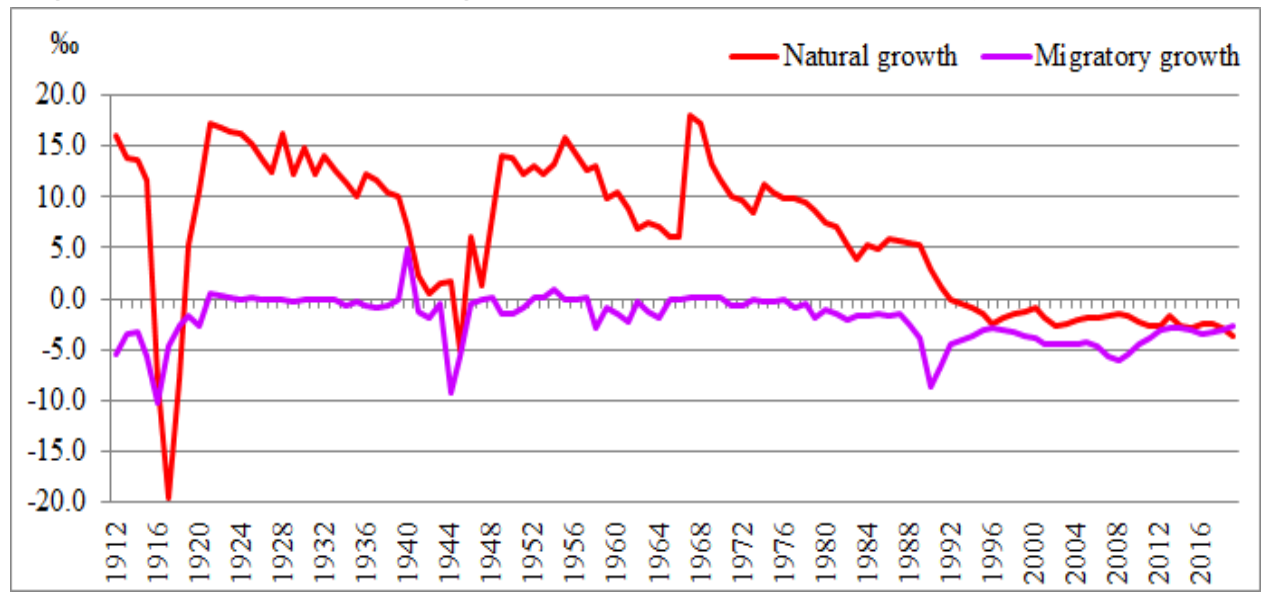

Source: Population movement bulletins and Statistical Yearbook of the 19122019 period.

These stages capture only the changes generated by international migration but the internal migration also faced important evolutions, both before and after 1990. Between 1966 and 1990, about 8.8 million people left their localities of origin, representing an impressive number compared to the 
total population, illustrative of the extent of the rural exodus. A similar number (over 9 million people, according to INS) left between 1990 and 2018, keeping the same pace but changing the direction of flows, initially in favour of the rural environment, then more and more towards abroad or towards the periurban areas of major cities, their attractiveness in the new context being due to the motorization of the population and change of lifestyle.

In the European context, Romania is grouped together with most states in the southeast of the continent, where the evolution of the migration balance clearly separates the period following the fall of totalitarian regimes, emphasizing its deepening negative character, simultaneously with the completion of the demographic transition. In the other European countries, the evolution of the migration balance logically followed the consumption of the demographic transition, which reduced the recovery capacity of its own labour force, stimulating immigration. This is captured by the typology of the combined evolution of the two balances, natural and migratory, during the period 1945-2019 (Figure 2).

Figure 2. Tipology of natural balance and migration balance in Europe

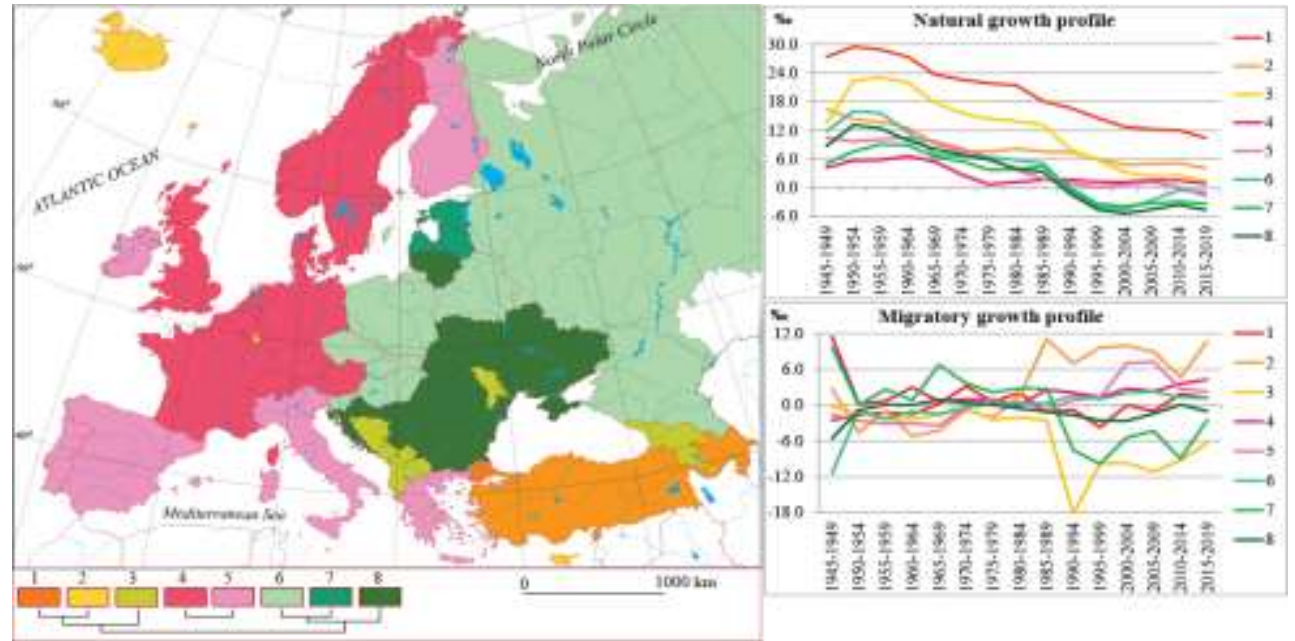

Source: Bardet, J.P., Dupâquier, J., (1999); Demographics (www.demographics, consulted in January 2021).

The historic moment of 1989 provided a real demographic shock at the continental level, disturbing the profile of the migration balance. Mediterranean states, traditionally marked by emigration, have become 
attractive and most communist states, stable until then, have fallen into the trap of a harmful combination - overlapping a deeply negative natural balance over an equally negative migratory balance, with no prospects for recovery. The relative homogeneity of the continent in the post-war period, marked by certain stability, without excessive attractiveness or repulsiveness, gave way after 1990 to heterogeneity, the new map of European migration being diverse, fragile and fragmented (King, 2019).

The main consequence of the shock generated by the fall of the communist regimes was the installation of a lasting population decline so that, if in 1990 Eastern European states held 48\% of the continent's population, in 2020 they had only 44\%, the decline being even more pronounced if we exclude the Russian Federation, transformed into an important regional attractor (Nefedova, 2015). The reversal of the evolution curves of the demographic indicators immediately after 1990 is also closely linked to the intensification of international migration. Although the last decade's data seem to reveal a weakening of the negative migration balance, it is rather related to the population's deepening aging process. Dependence on the increasing external migration input at the continental level can no longer be met by Eastern countries in the medium term. They themselves will need to attract a significant number of immigrants in order to maintain at least their current precarious demographic balance.

\section{Litterature review}

Domestic and international migration have generally been addressed separately, with an emphasis on the differences between them. Some classical analysis patterns have tried an integrated approach, at least from the perspective of the typology of the forms of manifestation and cycles of mobility transition (Zelinsky, 1971). The amplification of migration movements, in various forms, and the simplification of border transit procedures have led to a change in perception, favouring the integration of analysis models. This type of approach is especially indicated for emerging and developing states, in which the two major types of migration complement or succeed each other, as indicated by some studies (Vullnetari, 2013; Pieke and Mallee, 1999). The systemic approach, the issue of migrants' integration and the relationship between migration and development, as indicated by King and Skeldon (2010), can 
support an integrated view on the evolution of the two forms of migration. In general, the two forms of migration complement each other, they communicate, any increase in emigration being accompanied by a resizing of internal flows, as shown by some studies (Rotariu, Mezei, 1998).

From this perspective, Romania represents a particular case on the European scale. With a long-term internal migration directed towards the colonization of weakly populated areas (mountain or steppe), a late but strong rural exodus and a recent insertion in international migration flows, it provides a typical case of overlapping mobility transition stages (Cristescu, Muntele, 2007). The magnitude of the return flows directed towards deeply rural areas after the collapse of the communist regime and the crisis that followed it is another feature that subsequently generated a strong current of labour emigration, thus certifying the link between domestic and international migration (Dimitriu et al, 2013, pp.56-58). Unemployment, practically a previously unknown phenomenon, and the low level of wages, worsened by monetary instability, shaped the context of the amplification of this current between 1995 and 2005 (Silaghi, Subrata, 2011). Having a deeply regional character (expression of growing development disparities) and an amplitude similar to the rural exodus in the communist period, this form of international migration has practically changed Romania into the main provider of labour within the European Union (Goschin, 2016). The main origin of these flows is in the north-eastern areas, which before 1990 used to compensate the shortage of labour in the more developed areas of the country, certifying the presence of a continuity between domestic and international migration, as revealed by previous studies (Muntele, 2003). Although the motivations and strategies of the participants in these flows are different, due to their spatiotemporal manifestation, they represent a continuation of the communist epoch patterns. Internal migration flows thus combine and interconnect with external ones, an evolution that is, in fact, in line with the general European trends (Riccio, 2016, p.15). This process of emergence of a new migration system takes place against the background of the change of the causality and direction of flows, in the context of the transition from a quasi-closed system to an open one (Sandu, 2010, p.58-69). The evolution of the migration system in Romania is, in fact, part of the global trend of manifestation of the "new era of migrations", characterized by diversification, both from a territorial and social 
perspective (Anghel, Horváth, 2009, p.14). Global patterns of international migration have evolved in close connection with the change in the urbanization. Thus appears the distinction from internal migration, the main source of this process. Although the difference between international and internal has faded, each has a peculiarity that indicates rather separate study (Skeldon, 2005). Finally, any form of migration involves residential mobility, which often links internal and international migration (Pooley, 2021).

Having this theoretical basis, the general hypothesis of the present study is formulated as follows: the massive international migration observed in Romania after 1990 is a continuation of the massive rural exodus in the communist period (1948-1989), being determined by similar factors. The specific hypothesis is represented by the idea that the 1990 moment significantly modified the correlations between the analysed factors.

\section{Data and methodology}

In order to draw up the two analyses announced in the introduction, two distinct databases were created:

1) The evolution of the migration balance between 1948 and 2020, as it results from the following data series:

a) the population recorded at the censuses carried out throughout this time interval (1948, 1956, 1966, 1977, 1992, 2002 and 2011) and the one estimated by official sources for the year 2020 (the resident population, as registered in the Tempo-Online database of the National Institute of Statistics). The local administrative level (LAU) was used as a territorial basis of analysis, comprising the 3,181 officially recognized communes, cities and municipalities. The present approach took into account the administrative changes that occurred within the mentioned time interval, the reconstitution being mediated by the existence of detailed information at the level of the component villages;

b) the natural balance of the population for each intercensitary period, according to the natural movement of the population, as illustrated in the database mentioned above. For the period before 1966, we extrapolated the data aggregated on the intermediate administrative level between region and commune, specific to the epoch ("raion"), as it results from the statistical bulletins published by official statistics. In the case of the communes set up 
after 1990, we made use of the data of the commune they split from, proportionately reported.

The derived database contains 7 data series that illustrate the evolution of the migration balance, resulting from the difference between the general and the natural balance, expressed per 1,000 people. In order to highlight the existence of regional evolution patterns, an aggregative hierarchical clustering was performed in the Xlstat program. Class aggregation made use of the Euclidean distance and the Ward method, aiming at keeping a maximum dispersion of values between classes, thus ensuring a high degree of internal homogeneity. The results were represented graphically by means of a cartogram, further explained by the table that captures the evolution profile of each class.

2) The factorial database, using the migration balance as a dependent variable, for 2 distinct periods: 1948-1992 and 1992-2020. This separation was considered useful in order to highlight the specifics of the communist period and the changes that occurred during the transition period, respectively. The information used to create these variables and the standardization manner were both systematized and explained in a table (see Table 1). The factors were chosen so as to capture both the relationships between mobility and the socio-economic context and the possible influences of some physical-geographical components. The position of each locality within the administrative-territorial network was included to illustrate the classic dependence of human mobility on distance (Levy, 2010).

The derived database obtained by standardization was used for two principal component analyses (PCA), for each of the 2 periods, in the same Xlstat program. The last 5 variables were used only in the second analysis, lacking specific information for the 1948-1992 stage. The results were synthesized in correlative matrices. The $\mathrm{R}^{2}$ coefficient of determination obtained by multiple regression was also used for the further validation of the model.

\section{Model and findings}

\subsection{Descriptive analysis of the evolution of the migration balance between 1948 and 2020}

The use of the ascending hierarchical analysis model allowed the elaboration of a typology of the evolution of the migration balance with a validity 
ensured by a minimum dispersion of the values within each of the 8 identified classes (Figure 3). The profile of these classes differs according to the manifestation of processes such as urbanization, rural exodus, adaptation to the new post-communist context or insertion in the international migration circuits.

Table 1. Methodology of standardization of the variables used in the principal component analysis

\begin{tabular}{|c|c|c|c|}
\hline Variable & Data source & $\begin{array}{c}\text { Explanations and categories of } \\
\text { values }\end{array}$ & $\begin{array}{l}\text { Factorial } \\
\text { score }\end{array}$ \\
\hline $\begin{array}{c}\mathrm{MB}_{1}, \mathrm{MB}_{2} \\
\text { (Migratory } \\
\text { Balance for each } \\
\text { period) } \\
\end{array}$ & $\begin{array}{c}{[1948-2011} \\
\text { CENSUSES;INS] }\end{array}$ & $\begin{array}{c}\mathrm{MB}_{1} \text { concern } 1948-1992 \text { perioad } \\
\text { and } \mathrm{MB}_{2,1} 1992-2020 \text { period. Values } \\
\text { expressed in promiles }(\% \text { o) }\end{array}$ & Z score \\
\hline \multirow{6}{*}{$\begin{array}{l}\text { SET (Setting of } \\
\text { administrative } \\
\text { units in the } \\
\text { settlement } \\
\text { system) }\end{array}$} & \multirow{6}{*}{$\begin{array}{l}\text { According to the } \\
\text { current } \\
\text { administrative } \\
\text { division }\end{array}$} & a) cities; & 1 \\
\hline & & $\begin{array}{l}\text { b) metropolitan area (administrative } \\
\text { units situated at maximum distance } \\
\text { of } 30 \mathrm{~km} \text { from Bucharest, } 25 \mathrm{~km} \\
\text { from cities over } 200000 \mathrm{inh} \text {. and } \\
20 \mathrm{~km} \text { from cities over } 150000 \\
\text { inh.; }\end{array}$ & 0.8 \\
\hline & & $\begin{array}{l}\text { c) periurban area of medium-sized } \\
\text { cities (administrative units situated } \\
\text { at maximum distance of } 15 \mathrm{~km} \\
\text { from cities of } 50000-150000 \\
\text { inh.); }\end{array}$ & 0.6 \\
\hline & & $\begin{array}{l}\text { d) axial (along national roads and } \\
\text { railways); }\end{array}$ & 0.4 \\
\hline & & e) rural; & 0.2 \\
\hline & & $\begin{array}{l}\text { f) deep rural (administrative units } \\
\text { situated at minimum distance of } 50 \\
\mathrm{~km} \text { from main cities and } 40 \mathrm{~km} \\
\text { from medium-sized cities). }\end{array}$ & 0.05 \\
\hline \multirow{3}{*}{$\begin{array}{l}\text { DR (Risk of } \\
\text { drought) }\end{array}$} & \multirow{3}{*}[\mathrm{CEC}]{} & a) stressed; & 0.33 \\
\hline & & b) moderate; & 0.66 \\
\hline & & c) low/missing & 1 \\
\hline \multirow{4}{*}{$\begin{array}{l}\text { AFR (Degree of } \\
\text { afforestation }(\% \\
\text { of total area) }\end{array}$} & \multirow{4}{*}{ [INS] } & a) weak (under the $10 \%$ ); & 0.05 \\
\hline & & b) medium (10-25\%); & 0.33 \\
\hline & & c) high $(25-50 \%)$; & 0.66 \\
\hline & & d) very high (over the $50 \%$ ). & 1 \\
\hline \multirow{4}{*}{ SF (Soil fertility) } & \multirow{3}{*}{ [ADER] } & a) weak; & 0.33 \\
\hline & & b) moderate; & 0.66 \\
\hline & & c) high. & 1 \\
\hline & $\begin{array}{c}{[1966,1977} \\
1992,2002 \text { and }\end{array}$ & $\begin{array}{l}\text { a) dominantly agricultural (at least } \\
90 \% \text { employed in agriculture); }\end{array}$ & 0.05 \\
\hline
\end{tabular}




\begin{tabular}{|c|c|c|c|}
\hline \multirow{5}{*}{$\begin{array}{l}\text { SPS (Socio- } \\
\text { professional } \\
\text { structure) }\end{array}$} & \multirow[t]{5}{*}{$\begin{array}{c}2011 \\
\text { CENSUSES] }\end{array}$} & $\begin{array}{l}\text { b) agricultural (65-90\%, employed } \\
\text { in agriculture); }\end{array}$ & 0.2 \\
\hline & & $\begin{array}{l}\text { c) mixed (at least } 25 \% \text { populație } \\
\text { employed in each of the tree } \\
\text { activity sectors); }\end{array}$ & 0.4 \\
\hline & & d) mining (at least $25 \%$ employed); & 0.6 \\
\hline & & $\begin{array}{l}\text { e) industrial-tertiary (relatively } \\
\text { equal weight of secondary and } \\
\text { tertiary sectors); }\end{array}$ & 0.8 \\
\hline & & f) services (at least $65 \%$ employed). & 1 \\
\hline \multirow{4}{*}{$\begin{array}{l}\text { AGN (Ageing - } \\
\text { the share of the } \\
\text { population over } \\
60 \text { years) }\end{array}$} & \multirow{4}{*}{$\begin{array}{c}{[1966,1977} \\
1992,2002 \text { and } \\
2011 \\
\text { CENSUSES }]\end{array}$} & a) aging (over $40 \%$ elderly); & 0.05 \\
\hline & & $\begin{array}{l}\text { b) moderate aging ( } 25-40 \% \\
\text { elderly); }\end{array}$ & 0.33 \\
\hline & & $\begin{array}{l}\text { c) relatively young }(15-25 \% \\
\text { elderly); }\end{array}$ & 0.66 \\
\hline & & d) young (under the $15 \%$ ). & 1 \\
\hline \multirow{4}{*}{$\begin{array}{c}\text { DVT } \\
\text { (Demographic } \\
\text { vitality - the } \\
\text { share of the } \\
\text { population under } \\
\text { the } 15 \text { years) }\end{array}$} & \multirow{4}{*}{$\begin{array}{c}{[1966,1977} \\
1992,2002 \text { and } \\
2011 \\
\text { CENSUSES }]\end{array}$} & a) under the $15 \%$ young people; & 0.05 \\
\hline & & b) $15-22.5 \%$; & 0.33 \\
\hline & & c) $22.5-30 \%$; & 0.66 \\
\hline & & d) over $30 \%$. & 1 \\
\hline EMG & $\begin{array}{c}\text { [2002 and } 2011 \\
\text { CENSUSES] }\end{array}$ & $\begin{array}{c}\text { Emigration rate, expressed in } \\
\text { promiles }(\% \circ)\end{array}$ & Z score \\
\hline $\mathrm{NBH}$ & $\begin{array}{c}{[2002 \text { and } 2011} \\
\text { CENSUSES] }\end{array}$ & $\begin{array}{c}\text { Newly built homes, only for } 1990- \\
2019 \text {, relative to the total } \\
\text { population }\end{array}$ & Z score \\
\hline BST & [2011 CENSUS] & $\begin{array}{l}\text { Average weight of water supply, } \\
\text { sewerage and central heating for } \\
\text { each household }\end{array}$ & $\mathrm{Z}$ score \\
\hline EDU & [2011 CENSUS] & $\begin{array}{c}\text { Share of the population with high } \\
\text { school level and universities studies }\end{array}$ & Z score \\
\hline INC & $\begin{array}{l}\text { [2011 CENSUS; } \\
\text { INS] }\end{array}$ & $\begin{array}{l}\text { The average income calculated } \\
\text { according to the average wages of } \\
\text { each socio-professional category. }\end{array}$ & Z score \\
\hline
\end{tabular}

Source: Elaborated by the author

The first two classes comprise, on the one hand, the centres that experienced a constant attractiveness during the communist period (generally large and medium-sized urban centres indicated on the map) and on the other hand, the centres that stood out through an episodic, strong attractiveness, especially during the first decades (1948-1966). Mainly towns with a mining profile (in Jiu Valley) and mono-industrial towns fall into the latter category (Table 2). 
Figure 3. Typology of the evolution of migration balance (1948-2020)

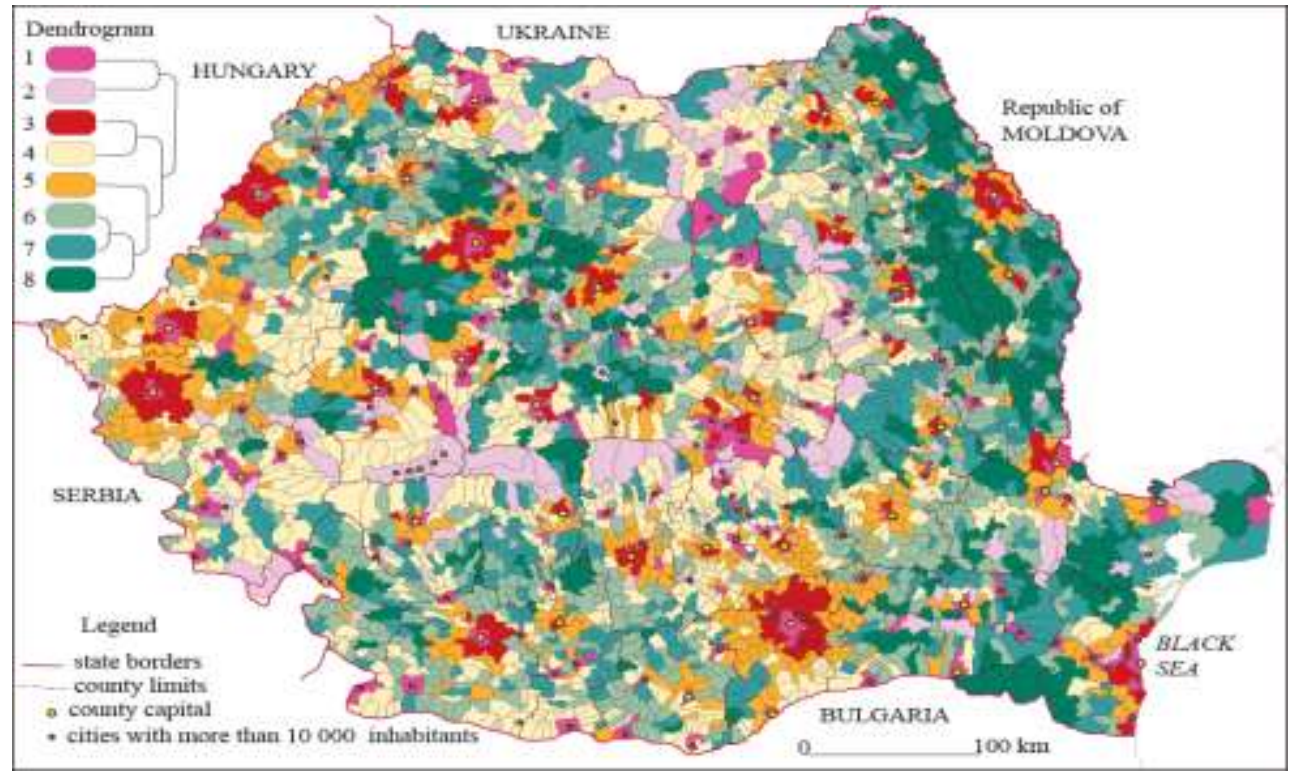

Source: CENSUSES from the period 1948-2011, Tempo-Online Database of National Institute of Statistics.

The next 6 classes are typical of the rural environment and were marked by the manifestation of the rural exodus during the communist period, in contrast to the period after 1990, when this trend got reversed.

Table 2: Profile of evolution types of migration balance

\begin{tabular}{|c|c|c|c|c|c|c|c|c|c|}
\hline \multirow{2}{*}{$\begin{array}{l}\text { Class } \\
\text { (type) }\end{array}$} & \multicolumn{7}{|c|}{ Migratory balance (\%) } & \multirow{2}{*}{$\begin{array}{l}\text { Number } \\
\text { of LAU }\end{array}$} & \multirow{2}{*}{$\begin{array}{c}\text { Share of } \\
\text { long-term } \\
\text { emigrants } \\
\text { (2011) }\end{array}$} \\
\hline & $\begin{array}{c}1948 \\
- \\
1956\end{array}$ & $\begin{array}{c}1956- \\
1966\end{array}$ & $\begin{array}{c}1966- \\
1977\end{array}$ & $\begin{array}{c}1977 \\
- \\
1992\end{array}$ & $\begin{array}{c}1992 \\
- \\
2002\end{array}$ & $\begin{array}{c}2002 \\
- \\
2011\end{array}$ & $\begin{array}{c}2011 \\
- \\
2020\end{array}$ & & \\
\hline 1 & 10.6 & 15.2 & 13.6 & 8.5 & -9.6 & -11.7 & -6.5 & 180 & 3.6 \\
\hline 2 & 22.7 & 5.5 & -12.3 & -7.5 & -7.4 & -9.6 & -5.3 & 128 & 5.7 \\
\hline 3 & -4.1 & -0.2 & -3.5 & -8.5 & 10 & 14.7 & 16.6 & 234 & 2.0 \\
\hline 4 & -5.1 & -6.5 & -6.8 & -7.8 & 0.6 & -3 & -2.3 & 814 & 3.3 \\
\hline 5 & -3.8 & -10.1 & -11.8 & -11.5 & 5.5 & 2.2 & 2 & 395 & 2.2 \\
\hline 6 & -5.9 & -13.8 & -15.8 & -14.4 & 3.9 & -4.2 & -3.9 & 563 & 4.3 \\
\hline 7 & -5.1 & -11.2 & -15.7 & -14.5 & -4.1 & -6.3 & -4.5 & 497 & 5.5 \\
\hline 8 & -7.1 & -18.1 & -28.4 & -22.6 & 1.8 & -5.7 & -5 & 370 & 3.4 \\
\hline $\begin{array}{l}\text { National } \\
\text { average }\end{array}$ & 0.1 & -0.6 & -0.3 & -1.9 & -3.7 & -5.6 & -1.8 & & 3.6 \\
\hline $\begin{array}{c}\text { Urban } \\
\text { population }\end{array}$ & 11.8 & 17.4 & 18.3 & 8.5 & -8.6 & -9.1 & -4.6 & & 3.6 \\
\hline $\begin{array}{c}\begin{array}{c}\text { Rural } \\
\text { population }\end{array} \\
\end{array}$ & -4.5 & -9.8 & -12.4 & -12.1 & 1.6 & -1.4 & 0.9 & & 3.6 \\
\hline
\end{tabular}

Source: CENSUSES from the period 1948-2011, Tempo-Online Database of National Institute of Statistics. 
The first two classes (3-4) recorded, between 1948 and 1992, moderately negative values of the migration balance, ranging between 0 and $-10 \%$ annually. In the case of class 3, the period 1956-1966 stood out through values close to 0 , this balance being explainable by the predominantly periurban position of the administrative units grouped in this class. The development of daily movements (commuting) provided a demographic stability. Subsequently, as the labour force demand of cities increased and the differences induced by the living standard deepened, the rural exodus was resumed even in these localities. After 1990, the two classes had divergent evolutions; the former rallied a strong periurbanization trend, the latter preserved a fragile balance. Typical especially of the Carpathian and Subcarpathian areas, class 4 can be considered safe from the harmful effects of the rural exodus which has never reached values capable of disturbing its demographic balance. From the point of view of its spatial extension, it is the most representative, but also the most dispersed.

The last 4 classes are differentiated by the deeply negative values of the migration balance during the communist period, followed almost everywhere by a recovery, even in the case of those which preserved their negative values. Their geographical position is closely linked to the distance to (especially important) urban centres. Class 5 groups the administrative units which are closer to cities, forming extended aureolas around large cities, continuing or mixing with class 3, with which it resembles in terms of the obvious manifestation of periurban attractiveness after 1992, even if at a lower level. Classes 6 and 7 experienced a common evolution before 1992, being deeply affected by rural exodus, but later they followed significantly different trends: class 6 registered an obvious recovery in the first post-communist decade, being specific mainly to plain areas; class 7 is practically the only one which preserved a negative migration balance, at a moderate level however, being typical of more isolated hilly or Subcarpathian areas. The difference between them can be explained by the preference of the urban population for rural areas with available agricultural land, thus hilly areas being disadvantaged. It is no coincidence that they were the first to experience labour emigration (northern Transylvania, Maramureș and Moldavian Subcarpathians, for example). Class 8 includes the most isolated rural areas, located mainly in the east of the country, but also in Transylvania, massively affected by rural 
exodus, especially between 1966 and 1992. This also explains the positive migration balance recorded between 1992 and 2002, resulting from the return of part of the previously emigrated population, the lower population density thus creating availability of agricultural land. The resettlement of the migration deficit in the last two decades is the premise of an imminent depopulation, which has become effective in the small areas in the west of the country (Lipova Hills, Apuseni Mountains, Poiana Ruscăi Mountains).

The image provided by this typology largely agrees with the logic of the mobility transition. Attractiveness is increasingly becoming an exclusive attribute of large and medium-sized cities, with an important administrative role. It is only them that "afford" the establishment of some attractive periurban aureolas, combining internal flows but also marginally attracting external flows, too (especially in the case of the capital and the cities of Iasi, Cluj and Timisoara).The peripheral rural areas and those strongly affected by restructured industrial activities have joined the path of the new rural exodus, mainly directed abroad (classes 2, 6 and 7). After a short period of turbulence during which rural areas seemed to experience a revitalization due to the absorption of the population driven out of cities by the reforms imposed by transition (1990-2002), there was a strong spatial segregation among the areas favoured by the early metropolitanisation process (classes 3 and 5), those who force themselves to maintain a fragile balance (class 4) and those who are doomed to depopulation, being often left out of a minimal modernization of infrastructure (class 8).

\subsection{Principal component analysis}

The database obtained by standardization, according to the specifications in the methodological chapter, served multivariate analyses. The option for the principal component analysis aimed at testing the hypotheses formulated in the introduction. Even if the analysis model used, the one proposed by Xlstat (produced by Addinsoft), provides coefficients for validity determination (Chisquare, $p$-value) multiple regressions were also performed in order to indicate the multiple coefficient of determination $\left(\mathrm{R}^{2}\right)$. The values obtained for all these coefficients, in the case of both analyses, specific to each period (1948-1992 and 1992-2020, respectively), certify the predictive value of the explanatory variables introduced in the model (tables 3, 4, Figure 4). 
be considered interesting, the aging process, recurrent after the rural exodus, being higher in isolated areas, with less fertile soils.

For the second period, five additional variables (especially EMG) were introduced in order to test the extent to which there is a link between the evolution of the migration balance and emigration.

Table 4. Correlation matrix (Pearson (n)), for the 1992-2020 period

\begin{tabular}{|c|c|c|c|c|c|c|c|c|c|c|c|c|c|}
\hline 12 & MB1 & SET & DR & AFR & $\overline{\mathrm{SF}}$ & SPS & AGN & DVT & EMG & $\mathrm{NBH}$ & BST & INC & EDU \\
\hline MB1 & 1 & 0.257 & -0.079 & -0.236 & 0.242 & 0.089 & 0.135 & 0.006 & -0.167 & 0.290 & 0.037 & 0.090 & 0.108 \\
\hline SET & & 1 & 0.017 & -0.074 & 0.191 & 0.498 & -0.207 & 0.111 & 0.130 & 0.338 & 0.508 & 0.382 & 0.388 \\
\hline$\overline{\mathrm{DR}}$ & & & 1 & 0.494 & -0.359 & 0.341 & -0.003 & 0.137 & 0.145 & 0.156 & 0.328 & 0.259 & 0.283 \\
\hline AFR & & & & 1 & -0.465 & 0.278 & 0.011 & 0.175 & 0.228 & 0.174 & 0.289 & 0.210 & 0.257 \\
\hline SF & & & & & 1 & -0.039 & 0.230 & 0.273 & 0.242 & 0.322 & 0.082 & 0.253 & 0.211 \\
\hline SPS & & & & & & 1 & -0.069 & 0.260 & 0.316 & 0.448 & 0.745 & 0.693 & 0.702 \\
\hline AGN & & & & & & & 1 & 0.132 & 0.407 & 0.404 & 0.003 & 0.408 & 0.374 \\
\hline DVT & & & & & & & & 1 & 0.696 & 0.640 & 0.391 & 0.542 & 0.513 \\
\hline EMG & & & & & & & & & 1 & 0.707 & 0.486 & 0.664 & 0.636 \\
\hline NBH & & & & & & & & & & 1 & 0.618 & 0.768 & 0.781 \\
\hline BST & & & & & & & & & & & 1 & 0.793 & 0.828 \\
\hline INC & & & & & & & & & & & & 1 & 0.940 \\
\hline EDU & & & & & & & & & & & & & 1 \\
\hline \multicolumn{14}{|c|}{ Chi-square $($ observed value $)=32368.2 ;$ Chi-square $($ critical value $)=99.617 ;$-value $<\mathbf{0 . 0 0 0 1}$; } \\
\hline \multicolumn{14}{|c|}{ Values in bold are different from ) with a siginificance level alpha $=\mathbf{0 . 0 5}$; Shaded values : dependent variable } \\
\hline & & & & & & & & & $\mathrm{Co}^{2} \mathrm{P}^{2}$ & .357 & & & \\
\hline
\end{tabular}

Source: Elaborated by the author

Closely related to this, NBH, BST, INC and EDU were introduced to test the importance of life quality, income, level of education and impact of emigration seen in terms of new housing construction. Although the R2 coefficient of determination is lower, it registers a significant value that increases if the last four factors, strongly correlated with EMG, are dropped out. This redundancy is not surprising, a large part of the remittances of labour emigrants being invested in the construction of new homes or in improving building comfort (Zamfir et al, 2010). At the same time, the level of education and the level of income have a significant role in stimulating emigration among highly qualified people (Goschin, 2013; 2016). These correlations confirm the predominance of economic reasons among the participants in the massive Romanian labour emigration flows. 
In comparison to the previous period, it stands out through significant correlations and physical-geographical factors. AFR and SF, although apparently opposite, explain the dependence of the migration balance (at least between 1992 and 2002) on the phenomenon of rural retreat of a part of the population previously migrated to cities.

Figure 4: Factor loadings (axes D1 and D2) for the 2 PCA conducted
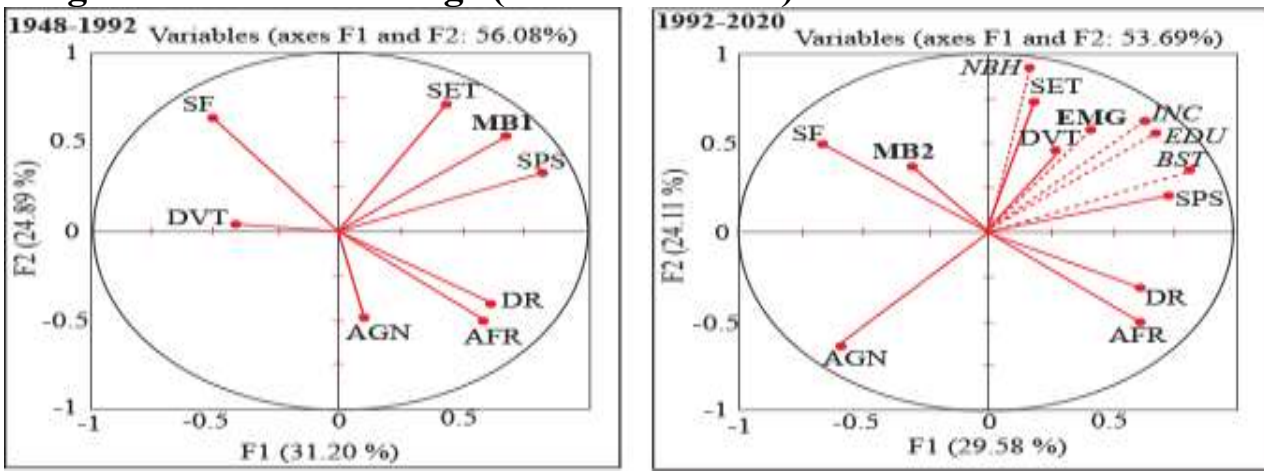

Source: Elaborated by the author

This phenomenon takes place especially in hilly and plain areas, with an agricultural potential and higher land availability than in hilly and mountainous areas, which are more forested. Factors which were strongly correlated in the first period, such as SPS, are now less important in the context of decreasing urban attractiveness and specific activities. The position within the settlement network preserves a certain importance, proving the decisive significance of this factor even in turbulent periods, as the transition to a market economy can be characterized. Among the newly introduced factors, NBH is significant, explainable primarily by the progressive insertion of periurbanization, accompanied by the expansion of living space.

The fact that EMG is negatively correlated, although not to a significant degree, is also important. It proves that the massive emigration after the year 2000 is primarily an urban phenomenon, regardless of the position within the network, strongly correlated with demographic vitality and the newly introduced factors in the model. The level of education, income and housing comfort, although higher in urban areas, favoured emigration by comparison to the situation in more developed countries, completely unfavourable. Thus EMG actually highlights the huge gap between urban and rural areas, which 
represents an additional repulsive factor, fuelling the propensity for emigration, as pointed out by other studies (Incalțărău, 2012). The fact that SPS, although correlated with EMG, has a lower coefficient, may indicate the generalization of emigration, regardless of the level of professional training, the diffusion of the phenomenon from urban to rural areas, through the development of some migration networks. The emergence of a new migration system in Romania by altering the causal structures and the configuration of flows is certified by the significant change in the correlations between the level of the migration balance and the considered factors. The introduction of some additional factors, with a certain predictive value, such as unemployment, would not significantly change the quality of the model, recent studies highlighting close correlations with the education level, income level or socio-professional structure, factors which have already been tested (Simionescu, 2020). Another category of factors with a specific predictive potential can be those of a cultural nature, such as ethnicity and religion, many migration channels getting inserted in this way, especially in regions with mixed population (Anghel, 2015). Once again, the results of the presented analyses bring out the complexity of the migration systems, the present study being able to be considered a starting point for complementary introspections or for deepening the observed connections and dependencies.

\section{Conclusions}

The relationships between domestic and international migration, as far as they could be probed by the proposed analysis model, do not have an easy to delimit coherence, as the principal component analysis shows for the second study period (1992-2020). If in terms of internal migration there is a continuity largely related to positional advantage, the international migration between 1948-1992 (manifested at a rather low level and almost exclusively of ethnic nature), stands out through the complete change of both its amplitude and spatial distribution. As demonstrated by the typological analysis, the isolated, repulsive regions have kept their exodynamic character, following the path of an inevitable depopulation, similar to those in the developed western countries. The urbanized regions or those that benefited from the exploitation of some resources experienced an almost brutal transition immediately after 1990, from attractiveness to repulsiveness. The 
extensive unidirectional movements that used to weld these two categories were interrupted by the end of the communist experiment. However, we can speak of continuity between domestic and international migration, starting from the presumption that a large part of those who participated in the authentic urban exodus after 1992 were those who had previously migrated from rural areas to cities, especially between 1977 and 1992. For this reason, the principal component analysis did not reveal a strong correlation between the migration balance and emigration. The massive international migration that characterizes the Romanian population in recent decades (about 4-5 million people according to unofficial figures but consistent with the statistics of the recipient states) is undoubtedly a continuation of the rural exodus in the communist period, at least from a motivational perspective. Just like then, the unavailability of jobs in the local or even zonal / regional horizon brought about massive movements. The opening provided by the numerous factories and industrial plants built by the communist regime, following some plans of territorial "harmonious" development, which in fact completely neglected its sustainable development, was most at hand in a closed system.

After 1990, the unlocking to the outside, the integration in the global circuits and the insufficiency / precariousness of the internal supply of jobs mobilize these masses abroad, in the most diverse activities. Basically, if by a miracle, the country were invaded by investments in activities in keeping with its real potential and needs, these masses would have every reason to return. It is possible that this will happen, but the return will no longer be towards the areas of origin but towards those which emerged as "winners" of the transition, the functional metropolitan areas, attractive for foreign investments and relatively adapted to the demands of a modern economy. The recovery of attractiveness by some cities seems a certainty, since the 2000s in the case of Cluj, more recently in the case of the capital, Timisoara, Iasi, Oradea or Sibiu, as shown by the descriptive analysis. At the regional level, a major discrepancy takes place between the Transcarpathian regions (evolving towards a competitive, multipolar model, in which medium-sized cities such as Alba Iulia or Bistrita have also got chances) and the southeastern regions, where the hypertrophy of the capital becomes an obstacle, of all the other cities only Iasi seeming to effectively behave like a regional pole. In the absence of possible corrections through well-founded regional and 
local development policies, these evolutions may be exacerbated. The state was rather content with the role of a passive spectator, literally "driving away" its citizens through the lack of coherent policies or through the inefficient use of the existing ones, especially in terms of illegal trafficking. Romania is facing an unprecedented demographic challenge, as other studies indicate (Borza, Soponaru, 2017). Internal migration from Romania was mainly driven by urbanization and industrialization planned before 1989. The transition to a market economy reversed this trend, gradually draining the flows of internal migration to the outside, motivated by development gaps. The effort to modernize the cities during the communist period neglected rural areas, the disparities thus created supplying the flows of international migration after 1990.

The study highlights the importance of multiple approaches in the study of migrations, the geographical perspective, provided by the amplitude of the worldview and the use of a varied methodology, being favourably placed to advance in the theorization of this vast field of research (King, 2011). The introduction of physical-geographical variables may further explain the formation of migration flows or the emergence of regional disparities, as underlined by this research. The combination of typological and factorial analyses also provides complementary results that can more accurately express the manifestation of spatial differentiations. The chrono-spatial perspective, using long series of data, as statistically coherent as possible, allows the detection of specific trends, ruptures, continuities, turbulences or invariabilities that more effectively explain the manifestation of evolution patterns. The proposed study tried to capture all these considerations in order to serve as a support for further research, aimed at analysing some observed features. The premise of the unitary approach of the two forms of migration, domestic and international, can also be productive in the direction of prospecting current or future trends.

\section{References}

Anghel, G.R., (2015). Migration in Differentiated Localities: Changing Statuses and Ethnic Relations in a Multi-Ethnic Locality in Transylvania, România. Population, Space and Place, 22(4), 356-366, Wiley. https://doi.org/10.1002/psp.1925 
Anghel, G.R., Horváth, I., (2009). Sociologia migrației. Polirom, Iași.

Bardet, J.P., Dupâquier, J., (1999). Histoire des populations de l'Europe, tome III. Fayard, Paris.

Bernard, A., Perales, F., (2021). Linking internal and internationl migration in 13 European countries: complementarity or substitution?. Journal of Ethnic and Migration Studies, 1-21, Taylor\&Francis. doi: 10.1080/1369183X.2020.1868983

Borza M., Soponaru C., (2017). The Socio-Demographic Changes in Romania: an Analysis from the Human Development Perspective. Eastern European Journal of Regional Studies, 3(1), 4-13. ASEM, Chișinău.

Bunea, D., (2012). Modern Gravity Models of Internal Migration. The Case of Romania. Theoretical and Applied Economics, volume XIX, 4(569),127-144, Bucharest.

Cristescu J., Muntele, I. (2007). Les conséquences humaines et territoriales $\mathrm{du}$ processus d'adhésion de la Roumanie à l'Union Européenne. L'information géographique, 71 (4), 121-144. Armand Colin, Paris.

Dimitriu, R., Muntele, I., Marcu, S., Dimitriu, A., (2013). Migrațiile internaționale ale populației din Moldova. Editura Universității "Alexandru Ioan Cuza" Iași.

Goschin, Z., (2016). Main Determinants of Romanian Emigration. A Regional Perspective, Journal of Social and Economic Statistics, special number, 1-13. https://mpra.ub.uni-muenchen.de

Goschin, Z., Roman, M., Danciu, A.R., (2013). The brain-drain phenomenon in Romania. Magnitude, characteristics, implications. Revista Economica, 65(5), 190-206, Bucharest.

Horváth, I., (2016). Internal migration transition in Romania?. Regional Statistics, 6 (1), 42-53. KSH, Budapest.

Încalțărău, C., (2012). Toward Migration Transition in Romania. CES Working Papers, 725-735. ceswo.uaic.ro

King, R., (2019). Diverse, Fragile and Fragmented: The New Map of European Migration. Central and Eastern European Migration Review, 8(1), 9-3. CEEOL.

King, R., (2011). Geography and Migration Studies: Retrospect and Prospect. Population, Space and Place, 18, p.134-153, Wiley. https://doi.org/10.1002/psp.685

King, R., Skeldon, R., (2010). 'Mind the Gap!'Integrating Approaches to Internal and International Migration, Journal of Ethnic and Migration Studies, $36 \quad$ (10), 1619-1646, $\quad$ Taylor\&Francis. https://doi.org/10.1080/1369183X.2010.489380 
Levy, M., (2010). Scale-free human migration and the geography of social networks, Physica A: Statistical Mechanics and its Application, $389(21)$, 4913-4917,

Elsevier. https://doi.org/10.1016/j.physa.2010.07.0008

Muntele, I., (2003). Migrations internationales dans la Roumanie moderne et contemporaine. In Diminescu, D. (coord.), Visibles mais peu nombreux. Les circulations migratoires roumaines (pp. 33-50). Editions de la Maison des sciences de l'homme, Paris.

Nefedova, T.G., (2015). Migration mobility of population and otkhodnichestvo in modern Russia. Regional Research of Russia, 5, 243-256. https://doi.org/10.1134/S2079980515030077

Pieke, F.N., Mallee, H. (1999). Internal and International Migration. Chinese Perspectives, Routledge.

Pooley C.G., (2021). Using life histories to explore the complexities of internal and international migration, Continuity and Change, 36(1), 111-131, Cambridge University Press. doi:10.1017/S0268416021000011

Rotariu, T., Mezei, E., (1998). Internal migration in Romania. In Heller, W., Romania: Migration, Socio-economic, Transformation and Perspectives of Regional Development, (pp.121-149). SüdosteuropaGesselchaft, München.

Riccio, B. (2016). From Internal to Transnational Mobilities. An Introduction, Emil, Bologna.

Sandu, D., (2010). Lumile sociale ale migrației românești în străinătate, Polirom, Iași.

Silaghi, M.I., Subrata, G., (2011). Why do not They Move from Rural to Urban Areas? Interegional Migration in Romania, Journal for Economic Forecasting, 1, 143-158, March. Institute for Economic Forecasting.

Simionescu, M., (2020). Improving unemployment rate forecasts at regional level in Romania using Google Trends. Technological Forecasting and Social Change, 155. https://doi.org/10.1016/j.techfore.2020.120026

Skeldon, R., (2017). International Migration, Internal Migrations Mobility and Urbanization: Towards More Integrated Approaches, United Nations Expert Group Meeting on Sustainable Cities, Human Mobility and International Migration, working paper, New York. www.un.org.

Skeldon, R. (2005). Interlinkages between internal and international migration and development in the Asian region. Population Space and Place, 12(1), 15-30, Wiley. https://doi.org/10.1002/psp.385 
Smith, D.P., (2011). Re-Making Migration Theory. Population, Space and Place, 18, 127-133, Wiley. https://doi.org/10.1002/psp.686

Vullnetari, J. (2013). Links between internal and international migration. In Ness, I. (edit.), The Encyclopedia of Global Human Migration, Wiley. doi: 10.1002/9781444351071. wbeghm346

Zamfir, A.M., Mocanu, C., Militaru, E., (2010). Impact of Remittances on Income Inequalities in Romania. In Schuerkens, U., Globalization and Trasnformations of Social Inequity (pp.61-79), Taylor\&Francis. https://doi.org/10.4324/9780203849255

Zelinsky, W. (1971). The hypothesis of the mobility transition. Geographical Review, 61(2), 214-249, Wiley-Blackwell.

Ministerul Agriculturii și Dezvoltării Rurale (2015). Harta potențialului tipurilor de sol din România. Proiect ADER 12.1.1, pp.23. Institutul de Cercetări Pedologice și Agrochimice, București. http:/geodim.meteoromania.ro/sia/proiect ADER 12.1.1, consulted between 1.06.2020-1.07.2020

Direcția Centrală de Statistică (1960). Recensământul populației R.P. România din 21.02.1956, vol.I-II, București.

Direcția Centrală de Statistică (1969). Recensământul populaţiei și locuințelor din 15.03.1966, vol. I-IV, București.

Direcția Centrală de Statistică (1981). Recensământul populației din 4.01.1977, vol. I-IV, București.

Comisia Națională de Statistică (1993) Recensământul populației și locuințelor din 07.01.1992, vol.I-III, București.

Institutul Naţional de Statistică (2003). Recensământul populaţiei și locuinţelor din 18.03.2002-Rezultate generale, București.

Institutul Naţional de Statistică (2014). Recensământul populației și locuințelor din 20.10.2002-Rezultate definitive, București.

Curtea Europeană de Conturi (2018). Raportul special al Curții Europene de Conturi (33/2018): Combaterea deșertificării în Uniunea Europeană. https:/op.europa.eu/webpub/eca/special-reports/desertification-332018/ro/, Romanian variant, consulted between 1.06.2020-1.07.2020

Institutul Central de Statistică. Mișcarea naturală a populației (1895-1948 editions), Bucharest.

Demographics. In Wikipedia (en.wikipedia.org/wiki/Demographics), consulted between 15.01.2015 and 15.01.2021)

Institutul Naţional de Statistică (2020). Populaţia și structura demografică. Tempo Online Database, consulted between 01.2019 and 03.2020 Institutul Naţional de Statistică (2020). Suprafața fondului forestier. Tempo Online Database, consulted between 06.2020 and 07.2020 